\title{
The 11 May 2011 earthquake at Lorca (SE Spain) viewed in a structural-tectonic context
}

\author{
R. L. M. Vissers ${ }^{1}$ and B. M. L. Meijninger ${ }^{2}$ \\ ${ }^{1}$ Department of Earth Sciences, Utrecht University, P.O. Box 80.021, 3508 TA Utrecht, The Netherlands \\ ${ }^{2}$ Fugro Engineers B.V., Leidschendam, The Netherlands \\ Received: 7 June 2011 - Published in Solid Earth Discuss.: 28 June 2011 \\ Revised: 2 September 2011 - Accepted: 13 September 2011 - Published: 5 October 2011
}

\begin{abstract}
The Lorca earthquake of 11 May 2011 in the Betic Cordillera of SE Spain occurred almost exactly on the Alhama de Murcia fault, a marked fault that forms part of a NESW trending belt of faults and thrusts. The fault belt is reminiscent of a strike-slip corridor, but recent structural studies have provided clear evidence for reverse motions on these faults. Focal mechanisms of the main earthquake, but also of a foreshock, are strikingly consistent with structural observations on the Alhama de Murcia fault. This strengthens the conclusion that, rather than a strike-slip fault, the fault is at present a contractional fault with an oblique reverse sense of motion, presumably in response to the NW-directed motion of Africa with respect to Europe.
\end{abstract}

\section{Introduction}

On 11 May 2011 at 16:47 UTC, the city of Lorca in the Betic Cordillera of SE Spain was hit by a magnitude 5.1 earthquake. While in general most events of this magnitude cause limited damage only, the Lorca earthquake led to 10 casualties, around 250 injured and considerable damage, such as the collapse of the antique church and several buildings and structural damage to many houses. The main reason for these serious effects was in all likelihood a very shallow hypocentre between 1 and $2 \mathrm{~km}$ depth at a distance of less than $2 \mathrm{~km}$ from the city. The main earthquake was preceeded by a 4.5 magnitude event for which different networks report different locations and focal depths of about $2 \mathrm{~km}$ east from Lorca at $0-1 \mathrm{~km}$ depth (United States Geological Survey, USGS), and $5 \mathrm{~km}$ east-northeast of Lorca at

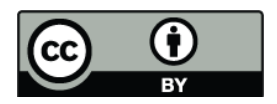

Correspondence to: R. L. M. Vissers (rvissers@geo.uu.nl)
$10 \mathrm{~km}$ depth (European Mediterranean Seismological Centre, EMSC). The main earthquake was followed by at least seven aftershocks with magnitudes between 2.6 and 3.9, four on the same evening, two on 14 May and one on 15 May (EMSC data).

Southern Spain forms a domain well known for its generally high seismicity (Fig. 1, inset) in response to AfricaEurope motions (Buforn et al., 1988, 2004; Masana et al., 2004; Stich et al., 2003, 2010). The city of Lorca is located immediately adjacent to a main fault zone called the LorcaTotana fault or, more commonly, the Alhama de Murcia fault. The fault forms part of a NE trending network of prominent faults, at first impression reminiscent of a strike-slip corridor, and bounds several Neogene and Quaternary intermontane basins (Fig. 1). This zone of prominent faults, characterized by marked seismicity (e.g. Stich et al., 2003), continues into the Alboran Sea (Montenat et al., 1987; De Larouzière et al., 1988; Montenat and Ott d'Estevou, 1990) in a belt of equally high seismic activity (Fig. 1, inset).

This short paper aims to draw attention to a remarkable consistency between the Lorca seismological data and recent structural analysis by the authors, and to emphasize that both datasets suggest oblique reverse rather than strike slip motions on significant portions of the Alhama de Murcia fault zone.

\section{The earthquake and its structural and tectonic context}

The Internal Zone of the Betic Cordillera in SE Spain is characterized by elongate mountain ranges of mainly metamorphosed Palaeozoic and Mesozoic rocks (e.g. Egeler and Simon, 1969; Platt and Vissers, 1989), separated by intermontane basins filled with Neogene to recent continental

Published by Copernicus Publications on behalf of the European Geosciences Union. 


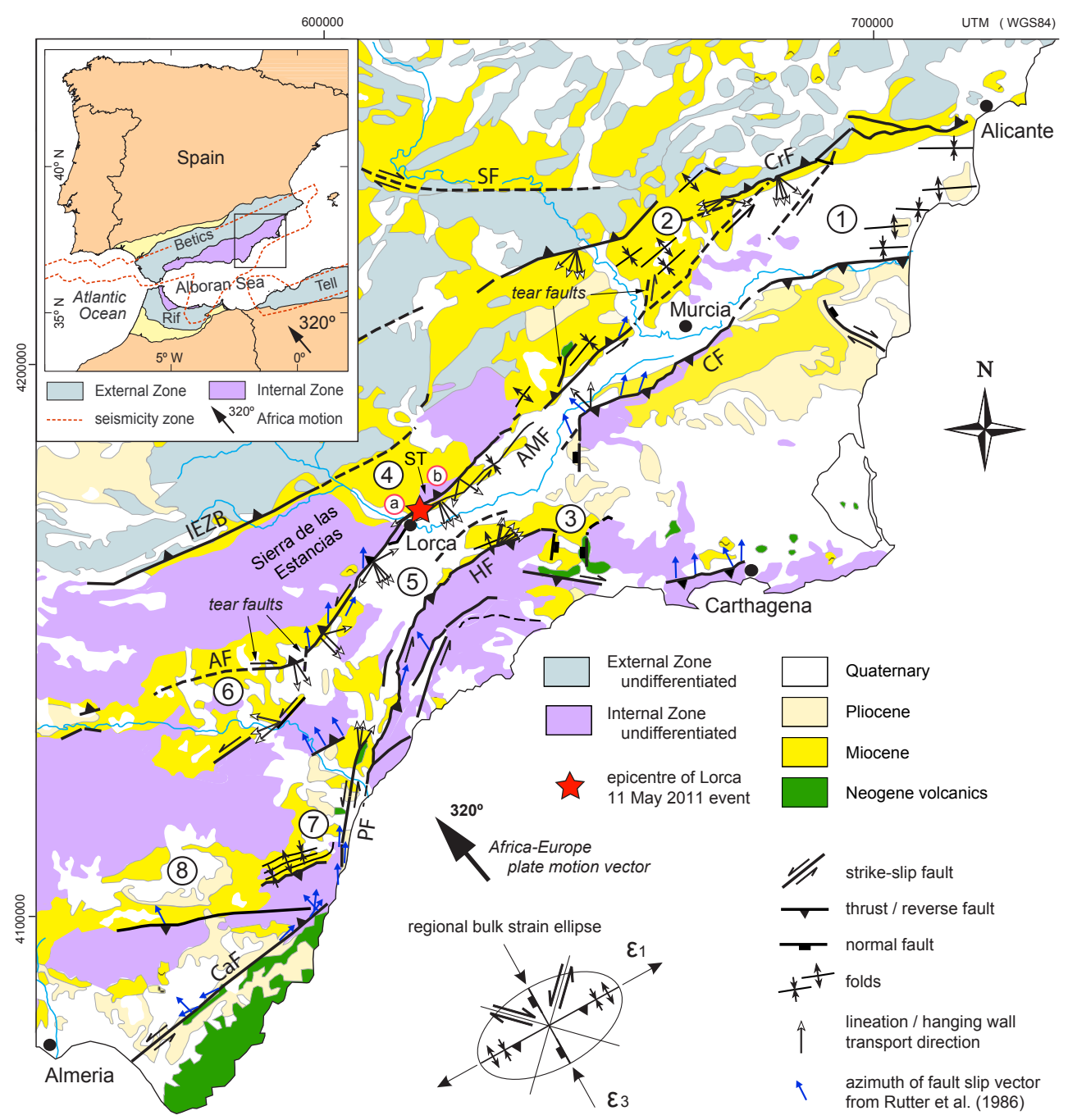

Fig. 1. Geological and structural-tectonic sketch map of SE Spain between Alicante and Almería showing the main Alhama de Murcia Crevillente fault belt, compiled after Meijninger and Vissers (2006). Numbers in circles refer to Neogene basins: (1) Alicante-Bajo Segura basin, (2) Fortuna basin, (3) Mazarrón basin, (4) Lorca basin, (5) Guadalentin-Hinojar basin, (6) Huercal Overa (Albox) basin, (7) Vera basin, (8) Sorbas-Tabernas basin. Abbreviations: AF Albox fault, AMF Alhama de Murcia fault, CaF Carboneras fault, CF Carrascoy fault, CrF Crevillente fault, HF Hinojar Fault, IEZB Internal-External Zone Boundary (or North Betic Fault), PF Palomares fault, SF Socovos fault, ST Sierra de la Tercia. Seismic zone in inset after Buforn et al. (1988). Slip vectors from Meijninger (2006) and Meijninger and Vissers (2006) represent either group averages or single measurements, based on striations on fault surfaces and shear planes in fault gouges, or movement directions determined from Riedel shear and P-foliation geometries in fault gouges. The data are supplemented with azimuths of fault slip vectors from Rutter et al. (1986). Roman letters a and b in circles near Lorca refer to fault exposures illustrated in stereographic projections of Fig. 2. Regional bulk strain ellipse based on structural data and fault-plane solutions from Jimenez-Munt et al. (2001), Stich et al. (2003) and Buforn et al. (2004). African-European plate motion vector from DeMets et al. (1994).

siliciclastics and overlying marine siliciclastic-carbonate facies sediments, marls and evaporites (e.g. Sanz de Galdeano, 1990). Current tectonic interpretations of these basins vary, from late-orogenic extensional structures in response to transient stages in the west Mediterranean lithosphere structure (e.g. Platt and Vissers, 1989; Lonergan and White, 1997; Spakman and Wortel, 2004), to a pull-apart origin associated with strike-slip movements along the NE trending network of prominent faults interpreted as major strike-slip faults (Mon- tenat et al., 1987; De Larouzière et al., 1988; Montenat and Ott d'Estevou, 1990, 1999). Late-orogenic extension in the western Mediterranen region has been interpreted in terms of convection (Platt and Vissers, 1989), lithospheric delamination (García Dueñas et al., 1992), and subduction rollback followed by slab detachment (Morley, 1993; Lonergan and White, 1997; Gutscher et al., 2002; Spakman and Wortel, 2004). Geologically recent to present-day tectonic activity is commonly viewed in terms of the late stages of 
such upper mantle processes, now dominated by ongoing motion between Africa and Eurasia (e.g. Vissers et al., 1995). Meanwhile, a strike-slip origin of the basins as suggested by Montenat et al. (1987) and De Larouzière et al. (1988) seems at variance both with recent structural studies of the underlying Betic basement and with the overall basin and fault geometry. In a recent study of the structure and kinematics of the Alhama de Murcia and Crevillente faults and of the synsedimentary structures in the late Miocene basin sediments, Meijninger and Vissers (2006) concluded that the late Miocene basins developed as genuinely extensional basins, presumably associated with the thinning and exhumation of the underlying basement at that time. During the late Miocene, neither the Alhama de Murcia fault nor the Crevillente fault further northeast near Alicante (Fig. 1) acted as strike-slip faults controlling basin development. Smaller scale synsedimentary faults and systematic thickening of upper Miocene strata towards the Alhama de Murcia fault indicate instead that at least part of the fault initiated as an extensional normal fault. Structural analysis of fault exposures and of the deformation of the adjacent sediments indicates that the Alhama de Murcia fault, and also the Crevillente fault, reactivated as contractional faults during the latest Miocene to early Pliocene. These faults at present act as reverse faults, with a movement sense of the hanging wall towards the $\mathrm{S}$ to SE. We now inspect the structural data on the Alhama de Murcia fault near Lorca in some detail.

Along the southern margin of the Lorca basin and along the Sierra de las Estancias southwest of Lorca, the Alhama de Murcia fault is a morphologically sharp, NE trending linear structure (Fig. 1) associated with the contact between basement rocks and mostly Quaternary basin sediments, and defined by a steep NW dipping fault. Kinematic indicators consistently indicate a sinistral reverse movement on this fault. Scarce outcrops of steeply tilted Miocene sediments of the footwall, oriented parallel to the main fault, reveal both layerparallel reverse and sinistral shear senses and are cut and displaced by NNE trending sinistral and WNW trending dextral strike-slip faults. These observations are clearly at variance with the commonly inferred dextral or sinistral strikeslip motions on these faults. The prominent faults form part of a larger scale zone of essentially post-Miocene shortening, made up of SSE and NNW-directed reverse faults and NE to ENE trending folds (Fig. 1), including thrust-related faultbend and fault-propagation folds, transected and displaced by, respectively, WNW and NNE trending, dextral and sinistral strike-slip (tear or transfer) faults.

Figure $2 \mathrm{a}$ and $\mathrm{b}$ show orientation data from two localities along the Alhama de Murcia fault near Lorca, the first one (a) from a domain of fault gouges about $2 \mathrm{~km}$ northeast of Lorca, the second one (b) about $4 \mathrm{~km}$ further northeast from the faulted contact between basement rocks of the Sierra de la Tercia and the basin sediments (Fig. 1). Data are after Meijninger and Vissers (2006). Whilst the gouge exposure shows few reliable (steep) Y-shears, linear features

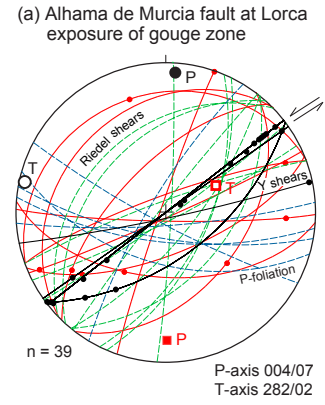

(b) Alhama de Murcia fault near Lorca thrusts at basement - basin contact

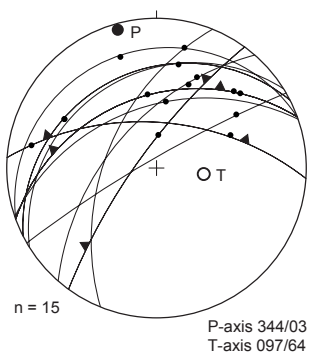

(c) poles to fault planes near $L$ rca data from (a) and (b) combined

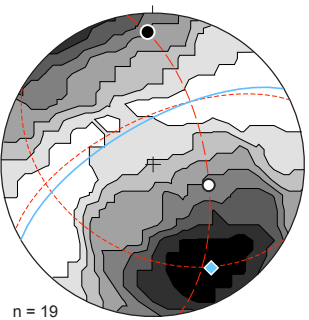

(d) lineations near Lorca data from (a) and (b) combined

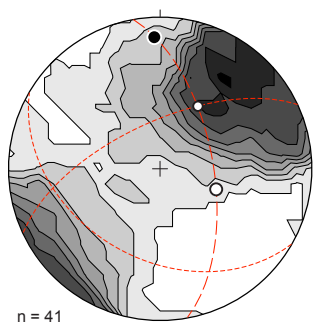

(e) Global CMT solution

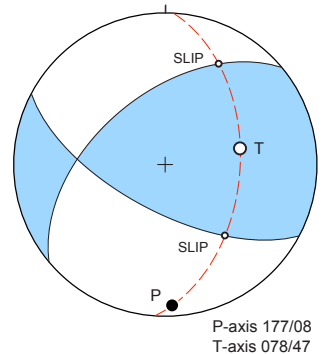

(f) GeoAZUR CMT solution

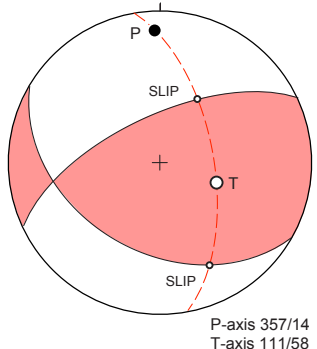

Fig. 2. Stereographic projections (equal area, lower hemisphere) showing orientations of faults and lineations in outcrops of the Alhama de Murcia fault near Lorca, from locations a and b indicated in Fig. 1, and focal mechanisms of the Lorca earthquake. (a) Structural data from fault gouge outcrop of location a near Lorca, after Meijninger and Vissers (2006). P and T axes denote the principal axes of incremental shortening and extension inferred from fault plane orientation, lineations on the fault plane and slip direction following Marrett and Allmendinger (1990). Data in red are striated fault planes, with related $\mathrm{P}$ and $\mathrm{T}$ axes in red. (b) Structural data from faulted basement-basin contact of location $\mathrm{b}$ about $5 \mathrm{~km}$ eastnortheast from Lorca, after Meijninger and Vissers (2006), with $\mathrm{P}$ and $\mathrm{T}$ axes as in (a) inferred from structural data. (c) Poles to fault planes from (a) and (b) contoured at $1 \sigma$ intervals using Kamb contouring. Diamond indicates average pole, greatcircle in blue is the corresponding average fault orientation. Dashed lines represent fault plane solution shown in (f), with $\mathrm{P}$ and $\mathrm{T}$ axes inferred from seismology. Note consistency of the average fault orientation with the NE striking nodal plane. (d) Lineations on fault planes combined from (a) and (b), contoured using $1 \sigma$ interval Kamb contouring. Dashed lines as in (c) denote CMT solution. Note consistency of the maximum density with the expected slip direction from the CMT solution (small white dot). (e) Global centroid-momenttensor (CMT) solution from the Global CMT Project. Dashed greatcircle representing plane through $\mathrm{P}$ and $\mathrm{T}$ intersects nodal planes along directions of expected slip. (f) GeoAZUR centroid-momenttensor (CMT) solution, dashed greatcircle as in (e) to show expected slip directions. 
such as striations on Riedel fractures and on the Y-shears mostly point to oblique motions of the NW wall. This applies even more clearly to the faulted basement-basin contacts of location (b) showing unequivocal structural evidence that the young motions on the Alhama de Murcia fault are oblique reverse with a sinistral component. This result is consistent with a kinematic study of the fault by MartínezDíaz (2002). The data combined from the two localities are shown in Fig. 2c and d as contour plots of respectively the poles to the fault planes and the associated lineations.

Inversion of the fault data following Marret and Allmendinger (1990) yields similarly oriented P but differently oriented $\mathrm{T}$ axes for the two localities. This may in part be due to limited sampling of reliable Y-shears (fault planes) from outcrop (a). Both, however, suggest an essentially NSdirected shortening $(\mathrm{P})$ axis governing the studied segment of the Alhama de Murcia fault near Lorca. Figure 2a in addition shows few striated fault planes from the gouge area yielding roughly similarly oriented $\mathrm{P}$ and $\mathrm{T}$ axes as in outcrop (b). We note, however, that Rutter et al. (1986) provide structural evidence for a genuine strike-slip motion from $\mathrm{R}$ and $\mathrm{P}$ structures in gouges about $4 \mathrm{~km}$ southwest of Lorca, so the results obtained from the exposed kinematics may vary somewhat along the fault zone.

The epicentre of the main magnitude 5.1 earthquake of 11 May 2011 is very close to Lorca $(<2 \mathrm{~km})$, almost on the Alhama de Murcia fault and within a few hundreds of metres from gouge exposure (a) according to the USGS data, or about $2 \mathrm{~km}$ further south according to the epicentre location by EMSC. Both USGS and EMSC report very shallow focal depths of respectively 1 and $2 \mathrm{~km}$. Fault plane solutions are available from both USGS and EMSC. USGS reports a USGS/SLU regional moment solution, and a centroidmoment-tensor (CMT) solution shown in Fig. 2e from the Global CMT Project using global long period body wave and surface wave data. We prefer the CMT solution for two reasons. First, it exclusively uses the low frequency signal of the seismogram which is less sensitive to scattering such that this solution is possibly more robust $(\mathrm{H}$. Paulssen, personal communication, 2011). Secondly, the CMT solution for the Lorca earthquake by the Global CMT Project is remarkably similar to CMT solutions obtained by the Instituto Geográfico Nacional (IGN) in Madrid and the French GeoAZUR, and both are significantly different from the USGS/USL regional moment solution.

In addition to the above fault plane solutions, CMT solutions have been reported by the Italian INGV and German GFZ that are similar to the USGS/SLU solution, hence also clearly different from the above CMT solutions and less consistent with the structural data discussed below. Aside from this latter aspect, there are two reasons that led us to discard the INGV and GFZ solutions. First, as noted above, there is a clear consistency of the global GMT solution with that of the Spanish IGN, and this latter solution is based on data from 64 seismic stations distributed over the entire Iberian Penin- sula. Secondly, the Italian INGV solution is based on data from the Italian seismic network, and this network is clearly in a geographically less favourable position to study an event in S Spain. The GFZ website indicates that their CMT solution for the Lorca earthquake, almost identical to the INGV solution, was done manually but, although unclear in this particular case, GFZ reports that lower magnitude events are commonly interpreted on the basis of up to 25 stations only.

Given the small differences between the CMT solutions of the Global CMT Project, the IGN and GeoAZUR, we now compare our structural data with (arbitrarily) the GeoAZUR solution presented in Fig. 2f, and show this solution in the contoured diagrams of Figs. $2 \mathrm{c}$ and d. The average orientation of the fault planes in Fig. 2c is very close to that of the NE-SW striking nodal plane. The dashed greatcircle through the $\mathrm{P}$ and $\mathrm{T}$ axes intersects the nodal planes along directions of expected slip, and Fig. $2 d$ shows that the NE plunging expected slip direction almost coincides with the density maximum of the contoured lineations. Note, in addition, that the $\mathrm{P}$ and $\mathrm{T}$ axes inferred from inversion of the fault kinematic data of locality (b) also agree well with the CMT solutions.

In addition to the above, EMSC also reports focal mechanisms for the mag 4.5 event at 15:05 UTC, preceeding the main earthquake. The fault plane solution from IGN is very similar to the CMT solutions of the main earthquake. It follows that the IGN focal mechanism is also in line with the structural data. Finally, EMSC reports one CMT solution by IGN for a mag 3.9 aftershock at 20:37 UTC of the same evening, about $9 \mathrm{~km}$ north-northwest of Lorca at $5 \mathrm{~km}$ depth. The corresponding fault plane solution has a $\mathrm{W}$ plunging $\mathrm{T}$ axis. We speculate that it may represent motion on a different fault than the foreshock and main earthquake. A cross-section through the main earthquake epicentre (location USGS) and perpendicular to the trend of the Alhama de Murcia fault (Fig. 3) shows the projected positions of the different events from 11-15 May with available focal mechanisms. The section is supplemented with a geological cross section across the Sierra de la Tercia and Alhama de Murcia fault from Meijninger and Vissers (2006) to illustrate the geological context.

\section{Discussion}

Structural analysis of the entire belt of prominent faults shown in Fig. 1 indicates that several segments of the fault network are at present contractional rather than strike- slip faults. A regional bulk strain ellipse based on the available structural data and fault-plane solutions from Jimenez-Munt et al. (2001), Stich et al. (2003) and Buforn et al. (2004) shows a shortening direction close to the African-European plate motion vector from DeMets et al. (1994). This result led Meijninger and Vissers (2006) to conclude that the latest Miocene to recent deformation on the fault network is controlled by the relative motion of Africa with respect to 


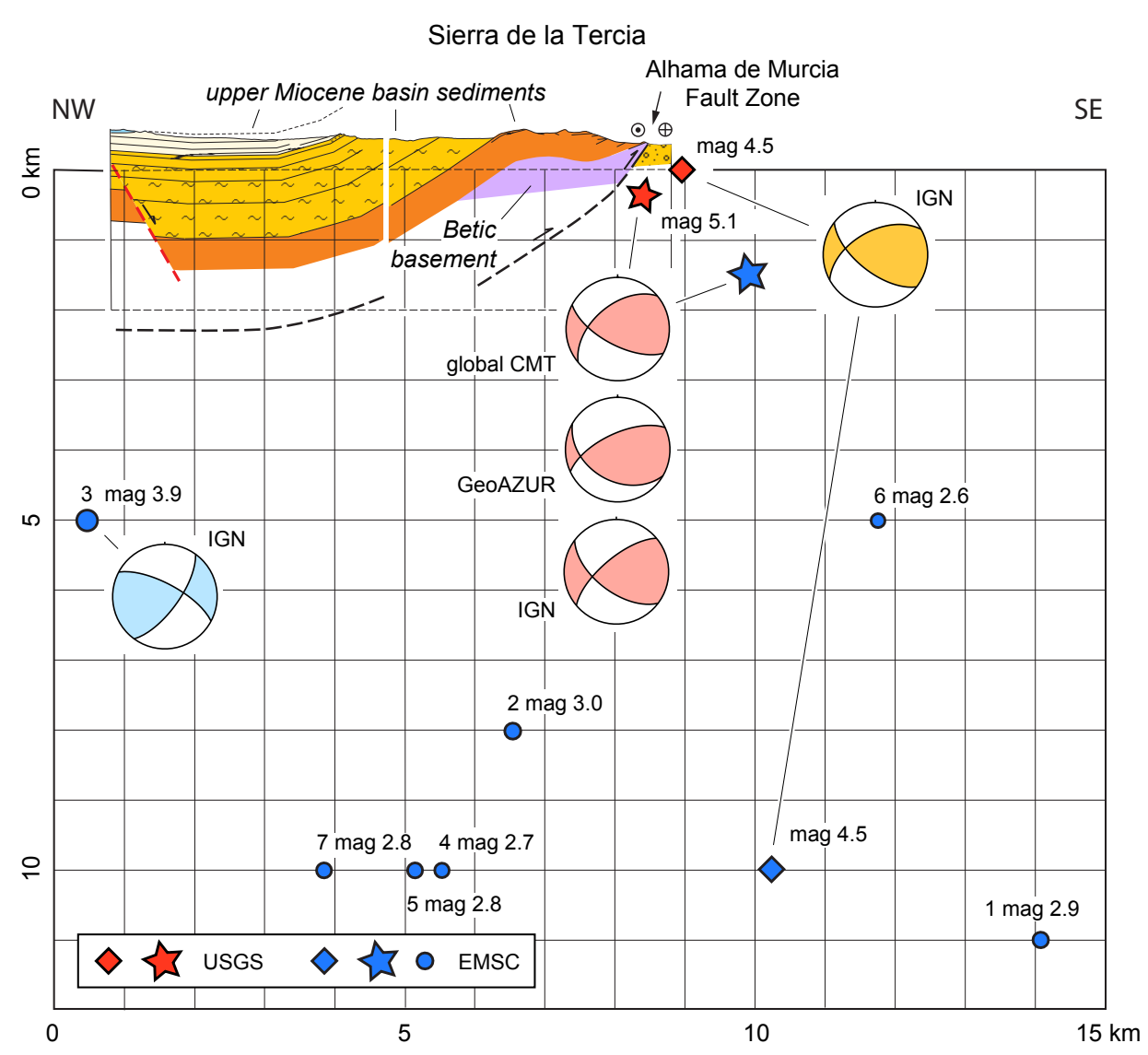

Fig. 3. Section across the Sierra de la Tercia and southern Lorca basin, perpendicular to the trend of the Alhama de Murcia fault and through the epicentre location of the main mag 5.1 earthquake from the USGS, with reported seismic events and fault plane solutions. All fault plane solutions are shown as seen in a map view (i.e. with the periferal circle horizontal). Diamonds: foreshock, stars: main earthquake, circles: aftershocks. Geological section from Meijninger and Vissers (2006). For further explanation see text.

Europe. In a study of the June 1977 earthquake near Lorca, however, Mezcua et al. (1984) report a focal mechanism indicating NW-SE directed extension, i.e. an extensional normal fault motion allegedly on the same Alhama de Murcia fault. We are puzzled by that observation and have as yet no explanation, because it seems inconsistent with the structural field data from the fault zone and with the current Africa motion, as inferred by DeMets et al. (1994). It is also inconsistent with the results of a detailed paleoseismological study of the fault by Masana et al. (2004), equally indicating oblique left-lateral reverse slip, i.e. essentially contractional motions, over the last $27 \mathrm{kyr}$.

The section in Fig. 3 is obviously sensitive to errors involved in hypocentre location, while the number of events is small. Nevertheless, the fore-, main and aftershocks for which focal mechanisms are available would be consistent with an oblique thrust motion carrying the Sierra de la Tercia southward. The dashed thrust underneath the geological section is based on section balancing techniques, and it is difficult to ascertain if it exists as such and if that structure was active during the earthquake. A seismic section across the
Fortuna basin further northeast by Amores et al. (2001) reveals many steeply NW and SE dipping reverse faults down to $1.5 \mathrm{~s}$ TWT. It seems quite possible that such steeply oriented structures also exist underneath the Sierra de la Tercia and Lorca basin. At this point, we note that at least 4 aftershocks (labelled 2, 45 and 7 in Fig. 3) occurred at locations underneath the Sierra de la Tercia that could well be consisent with movements along such steep reverse structures.

\section{Conclusions}

There is a striking correspondence between the focal mechanisms of the 11 May 2011 Lorca earthquake as reported by USGS, ING and GeoAZUR, and structural data from the Alhama de Murcia fault. This reinforces the conclusion that the fault is presently a contractional fault with an oblique reverse sense of motion. This result is entirely consistent with the regional deformation pattern inferred from structural data, fault-plane solutions and numerical modelling, all suggesting a shortening direction close to the present-day direction of Africa-Europe convergence. 
Acknowledgements. We are indebted to Hanneke Paulssen and Paul Meijer for their constructive criticism, helpful advice and careful reading of the first version of the manuscript, and to E. H. Rutter and an anonymous reviewer for constructive discussion.

Edited by: R. Carbonell

\section{References}

Amores, R., Hernández-Enrile, J. L., and Martínez-Díaz, J. J.: Sobre los factores relacionados con la evaluación de la peligrosidad sísmica en la región de Murcia, 2o Congreso Iberoamericano de Ingeniería Sísmica, Madrid, Spain, Asociación Española de Ingeniería Sísmica, 2001.

Buforn, E., Udias, A., and Colombas, M. A: Seismicity, source mechanisms and tectonics of the Azores-Gibraltar plate boundary, Tectonophysics, 152, 89-118, 1988.

Buforn, E., Bezzeghoud, M., Udías, A., and Pro, C.: Seismic sources on the Iberia-African plate boundary and their tectonic implication, Pure Appl. Geophys., 161, 623-646, 2004.

De Larouzière, F. D., Bolze, J., Bordet, P., Hernández, J., Montenat, C., and Ott d'Estevou, P.: The Betic segment of the lithospheric Trans-Alboran shear zone during the Late Miocene, Tectonophysics, 152, 41-52, 1988.

DeMets, C., Gordon, R. G., Argus, D. F., and Stein, S.: Effect of recent revisions to the geomagnetic reversal time scale on estimates of current plate motions, Geophys. Res. Lett., 21, 21912194, 1994.

Egeler, C. G. and Simon, O. J.: Orogenic evolution of the Betic Zone (Betic Cordilleras, Spain), with emphasis on the nappe structures, Geol. Mijnbouw, 48, 296-305, 1969.

García-Dueñas, V., Balanyá, J. C., and Martínez-Martínez, J. M.: Miocene extensional detachments in the outcropping basement of the northern Alboran basin (Betics) and their tectonic implications, Geo-Mar. Lett., 12, 88-95, 1992.

Gutscher, M.-A., Malod, J., Rehault, J.-P., Contrucci, I., Klingelhoefer, F., Mendes-Victor, L., and Spakman, W.: Evidence for active subduction beneath Gibraltar, Geology, 30, 1071-1074, 2002.

Jimenez-Munt, I., Fernández, M., Torne, M., and Bird, P.: The transition from linear to diffuse boundary in the Azores-Gibraltar region: results from a thin-sheet model, Earth Planet. Sc. Lett., 192, 175-189, 2001.

Lonergan, L. and White, N.: Origin of the Betic-Rif mountain belt, Tectonics, 16, 504-522, 1997.

Marrett, R. and Allmendinger, R. W.: Kinematic analysis of faultslip data, J. Struct. Geol., 12, 973-986, 1990.

Martínez-Díaz, J. J.: Stress field variation related to fault interaction in a reverse oblique-slip fault: the Alhama de Murcia fault, Betic Cordillera, Spain, Tectonophysics, 356, 291-305, 2002

Masana, E., Martínez-Díaz, J. J., Hernández-Enrile, J. L., and Santanach, P.: The Alhama de Murcia fault (SE Spain), a seismogenic fault in a diffuse plate boundary: Seismotectonic implications for the Ibero-Magrebian region, J. Geophys. Res., 109, B01301, doi:10.1029/2002JB002359, 2004.
Meijninger, B. M. L.: Late-orogenic extension and strike-slip deformation in the Neogene of southeastern Spain, unpublished Ph.D. thesis, Universiteit Utrecht, 250 pp., 2006.

Meijninger, B. M. L. and Vissers, R. L. M.: Miocene extensional basin development in the Betic Cordillera, SE Spain revealed through analysis of the Alhama de Murcia and Crevillente Faults, Basin Res., 18, 547-571, doi:10.1111/j.13652117.2006.00308.x, 2006.

Mezcua, J., Herraiz, M., and Buforn, E.: Study of the 6 June 1977 Lorca (Spain) earthquake and its aftershock sequence, B. Seismol. Soc. Am., 74, 167-179, 1984.

Montenat, C. and Ott d'Estevou, P.: Eastern Betic Neogene basins A review, Documents et Travaux de l'Institut Geologique Albert de Lapparent (IGAL), 12-13, 9-15, 1990.

Montenat, C. and Ott d'Estevou, P.: The diversity of Late Neogene sedimentary basins generated by wrench faulting in the Eastern Betic Cordillera, SE Spain, J. Petrol. Geol., 22, 61-80, 1999.

Montenat, C., Ott d'Estevou, P., and Masse, P.: Tectonicsedimentary characters of the Betic Neogene basins evolving in a crustal transcurrent shear zone (SE Spain), Bull. Centr. Rech. Expl. Prod. Elf Aquitaine, 11, 1-22, 1987.

Morley, C. K.: Discussion of origins of hinterland basins to the Rif-Betic Cordillera and Carpathians, Tectonophysics, 226, 359376, 1993.

Platt, J. P. and Vissers, R. L. M.: Extensional collapse of thickened continental lithosphere: A working hypothesis for the Alboran Sea and Gibraltar arc, Geology, 17, 540-543, 1989.

Rutter, E. H., Maddock, R. H., Hall, S. H., and White, S. H.: Comparative microstructures of natural and experimentally produced clay-bearing fault gouges, in: International structure of fault zones, edited by: Wang-Chi, Y., Pure Appl. Geophys., 124, 3-30, 1986.

Sanz de Galdeano, C.: Geologic evolution of the Betic Cordilleras in Western Mediterranean, Miocene to the present, Tectonophysics, 172, 107-119, 1990.

Spakman, W. and Wortel, M. J. R.: A tomographic view on Western Mediterranean Geodynamics, in: The TRANSMED Atlas: The Mediterranean Region from Crust to Mantle, edited by: Cavazza, W., Roure, F., Spakman, W., Stamplfli, G. M., and Ziegler, P. A., Springer Verlag, Berlin, 31-52, 2004.

Stich, D., Ammon, C. J., and Morales, J.: Moment tensor solutions for small and moderate earthquakes in the Ibero-Maghreb region, J. Geophys. Res., 108, 2148, doi:10.1029/2002JB002057, 2003.

Stich, D., Martín, R., and Morales, J.: Moment tensor inversion for Iberia-Maghreb earthquakes 2005-2008, Tectonophysics, 483, 390-398, 2010.

Vissers, R. L. M., Platt, J. P., and van der Wal, D.: Late Orogenic extension of the Betic Cordillera and the Alboran Domain: A lithospheric view, Tectonics, 14, 786-803, 1995. 